\title{
The Presence of Dance in Female Deities of the Greek Antiquity
}

\author{
Lykesas Georgios ${ }^{1}$
}

Papaioannou Christina1

Dania Aspasia²

Koutsouba Maria²

Nikolaki Evgenia²

\begin{abstract}
${ }^{1}$ Department of Physical Education and Sport Science, Aristotle University of Thessaloniki, Greece ${ }^{2}$ School of Physical Education and Sport Science, National \& Kapodistrian University of Athens, Greece
\end{abstract}

Doi:10.5901/mjss.2017.v8n2p161

\begin{abstract}
According to philosophers and paedagogists, from antiquity until today, arts and dance in particular have played a determining role in shaping the human personality, as well as in helping people gain a positive perspective of their multi-aspect development in terms of knowledge, perception, creative ability, psychomotor actions, emotional and social elevation. This holistic and anthropocentric approach in antiquity set new ways for perceiving motion -particularly dance- through the dance education. The aim of this study is to provide a well-documented review of dance in religious events of the ancient Greek world, by collecting and processing data related to female deities connected to the most important dances and music in public feasts of Ancient Greece -feasts of both religious and war character. Dance, music and poetry; the three elements that managed to influence and configure the education of the Ancient Greeks, leading to one of the most fundamental elements of Greek aesthetics: "harmony".
\end{abstract}

Keywords: Dance, Ancient Greece, Female Deities, Religious Event

\section{Introduction}

Dance and worship were two entities closely interrelated in Ancient Greece. Dances would accompany all important 'transitions' in one's life: transition to puberty, to adulthood, to married life, even to death. Dancing and singing constituted a primary educational means for the youth and a substantial way to ensure that traditions and institutions of the community are passed on to the next generations. "Chorus", that is the combination of "ode" (song) and "orchesis" (dance), constituted an indirect way to establish the relationship between the citizen and the city, for in the ancient times it was believed that the dance represented a microcosm of the community. (Lucian. Peri orchiseos 15). So, in ancient Greece, the Philosophers, like Plato and Aristotle, recognized the valuable impact of arts, and dance in particular, on the general education of future citizens. They particularly valued dance, because it involved exercising that ensured health, beauty and flexibility. All the above, in conjunction with moral virtue, created an ideal framework for the development of both mind and body (Panagou- Michalakakos, 2003). The role of religion also contributed significantly to creating an imposing ambiance of respect and sanctity related to dance. It was believed that gods were the fathers of dances, since it was them who invented them; therefore, it was the boys \& girls' duty to participate in religious ceremonies and feasts

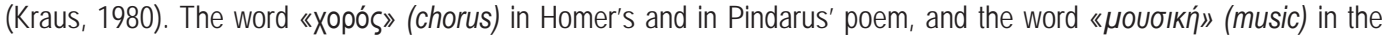
ancient tragedy, define the art that the Muses offered to humans (West, 1999). To Plato, "Xopós» (Plato, Laws 654B) also means unity, movement, sound and choral poetry- choral song.

First of all, "chorus" means "chorostasi", i.e. the place where the dance is performed; meeting point of the human and the divine realm. This is the place where groups with common traits (race, age, class) or common purpose (prayer of invocation to god, thanking and expressing gratitude to god, celebrating) join together; a place where one can see and be seen, choose and be chosen, as happens for example in mixed dances (danced by both men and women). The second meaning of the word chorus is "orchesis". Orchesis (dance) though had a wider sense compared to today, since it could denote any kind of rhythmically repeated movement of feet, hands, head, eyes or even the whole body (Plato, Laws $653 c-d, 665 a)$. To the Ancient Greeks, the principle of the art of orchesis, as of every form of art, was "mimesis" 
(imitation). The third meaning is connected with the animate material, the group of dancers (chorus) that determines the place where they dances (chorus) through the specific dancing ritual movement (chorus). The circle, in particular, creates a community, unites the members of a group with common traits (external beauty, youth, age, origin etc) (Papadopoulou, 2004).

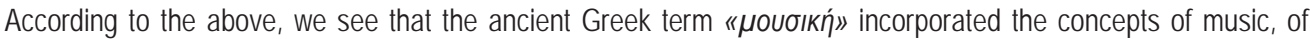

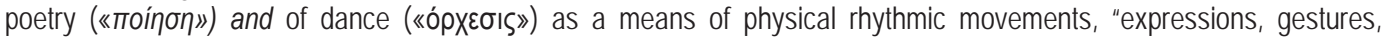
postures", that all have rhythm as their common element (Neubecker, 1986). The most fundamental objective of arts is to

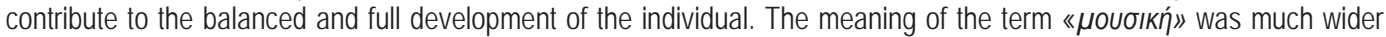

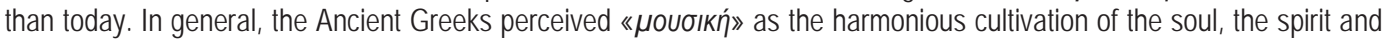
the body (Mouratidis, 1998). According to Plato and the other Greek Philosophers, music is not simply the movement of sounds organized by humans, but rather something much deeper and more pluralistic. It is the harmonious relationship among the three forms of expression of the human existence: movement as "expression of the body", speech as "expression of thoughts" and sounds as "expression of emotions") (Kyminou-Printaki, 1998). These three components of

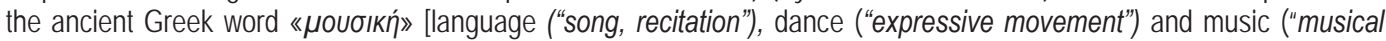
performance")] correspond to the elements comprising the human existence, which are the spirit, the body and the soul. (Alexiadou, 1999).

Plato (427-347 B.C.) believes in the powerful positive effect of "music" on the soul and emphasizes its necessity, regarding it as a substantial ingredient and essential educational means along with gymnastic exercises, for the development and shaping of the human personality (Plato. Laws 814-817). This is the reason why he supported that « young, aiming at the unification of the soul, the spirit and the body, with the exception though of all wild, orgiastic and

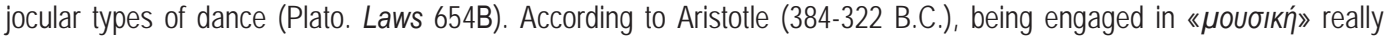

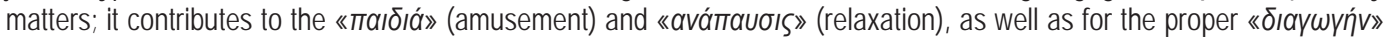
(conduct, behavior). In addition to all this, music also has the particular quality of cultivating "ethos" (morals) and the soul of citizens (Aristotle. Politics 1337a-1340b). From the literary works of the Ancient Poets and the witnesses of Historians, as well as from the works of Visual Arts that have been saved, we learn quite many data about names and types of dances, postures and gestures, the general character of every type, the contributors and occasions for dancing. In the same way we learn about the presence of female deities associated with the dance in Ancient Greece. Today it is difficult to replicate the kinesiology of the ancient Greek dances and lost melodies (Themelis, 1989, 1994). Numerous representations and reliefs, particularly of the $5^{\text {th }}$ century B.C., as well as countless statues of Greek sculpture were inspired from the orchestic art, depicting deities, maenads and smaller deities or beautiful girls dancing (Mouratidou, et al., 2002). More specifically, we frequently meet goddess Cybele, the Muses very often holding musical instruments, and the Maenads dancing and playing music in a state of ecstasis (Kopsachilis, 1992). Other female deities related to dance were Artemis, Aphrodite, Dimitra, as well as her daughter Persephone (Kraus, 1980).

A great deal of information also derives from archaeological sources, including statues, reliefs, woodcarvings, frescoes, ceramic vessels, many of which depict real dance scenes with female deities.

Documentation of evidence concerning the role of dance in religious events and female deities closely connected with dance, is conducted by investigating the primary sources of "Ancient Greek Literature", along with the contemporary sources "Scientific Articles and Essays".

The aim of this paper is to present an integrated and documented picture of the presence of dance in religious events in the ancient Greek world, by collecting and processing data related to female deities connected to the most important dances and music in public feasts of Ancient Greece -feasts of both religious and war character.

The methods used for the data collection and processing are the analytic-synthetic method and the historical method respectively, aiming at demonstrating the particular significance and status of the dance in religion by studying diachronic events and causes that explain the existence of any type or form of dance (Adshead, \& Layson, 1986).

Thus, this study documents the presence of female deities associated with dance, including the Muses, the Nymphs, the Maenads, Artemis, Aphrodite, the Graces (Charites), Dimitra, Persephone and Cybele.

\section{The Muses}

The most ancient monument of Greek literature are Homer's epic poems. In the war world of the lliad, as normally expected, music and dance appear more rarely. However, there is reference in the symposium of the gods on Mount Olympus, where Apollo himself plays the phorminx, while the Muses sing and dance gracefully (Homer. lliad A 472-474, 603-4, B 594-600). The Ancient Greeks with their inventive reflection, attributed divine origin to everything, including of 
course dance and music. As a result, they made up the nine Muses (Clio, Euterpe, Thalia, Melpomene, Terpsichore, Erato, Polyhymnia, Urania, Calliope), daughters of Zeus and Mnemosyne, initially goddesses of song and later on of poetry and other arts and sciences. According to Hesiod, the Muses were born in Pieria, and that is why they were also called "Pierides" (Pierian Muses) (Hesiod., Projects and days 1, Theogony 1-115, 346-348, Shield 200-206). Their leader was "Apolo Mousagetes" (Apollo Muse-leader), who was the god of light, prophecy, music and poetry (Kakridis, 1986). In Iphigenia in Aulis, Euripides writes: "the fair-tressed Pierides with the dancing guitar and reedy flutes beat the ground with

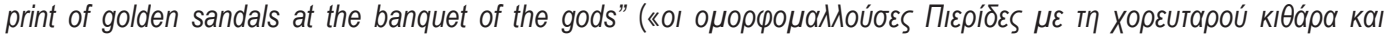

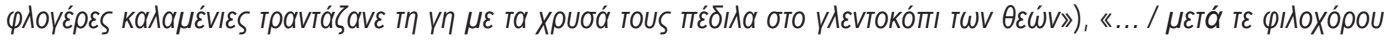

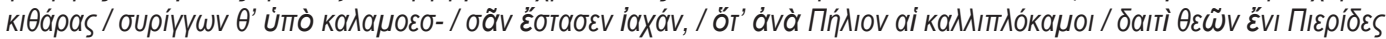

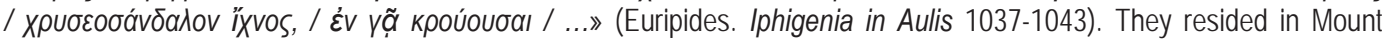

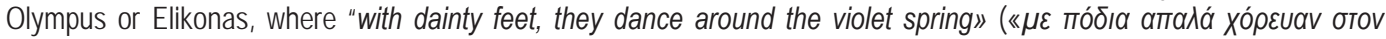

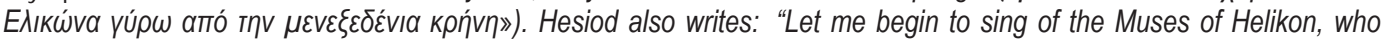
abide on the great and holy Mount Helikon. Around the deep-blue spring, with dainty feet, they dance, and around the

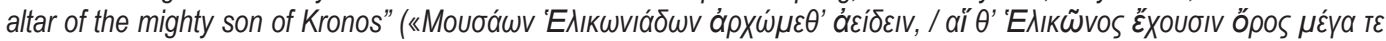

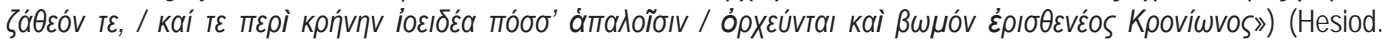
Theogony 63, 1-4). In Elikonas Mountain, as says the inscription, sits the Muse depicted on the vessel fully absorbed in playing her guitar, while another Muse that is not visible, listens to her with absolute devotion. (Fig. 1).

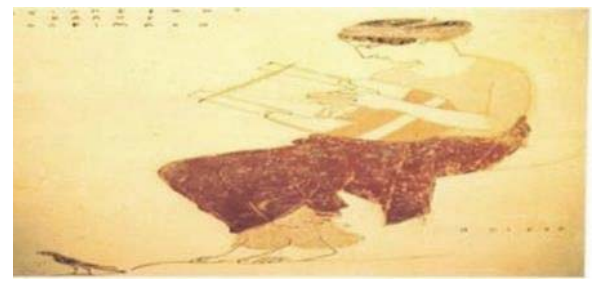

Figure 1. Muse. White lekythos (oil flask) by Achilles' Painter, around 440 B.C. /Munich, Staatliche Antikensammlunge. Beazley, ARV2, 997.155.

The subject of the songs was always the noble origin of gods, whom they praised. The harmonious song of the Muses enchanted the king of gods and humans, overflew all gods' souls with euphoria and charmed the entire nature, which stood spellbound every time their song was heard at the top of Mount Olympus (Hesiod. Theogony 56-93; Homer. Hymn to Apollo 185-189). They were considered to be the goddesses of music and poetry, who all together exalted Zeus with their melodious voices (Homer. Iliad B 484-486; Hesiod. Theogony 11; Kakridis, 1986). Referring to the Muses' dance, Hesiod, who himself had seen them dancing around his father's altar, writes characteristically: "...and, when they have washed their tender bodies in Permessus or in the Horse's Spring or Olmeius, make their fair, lovely dances and move

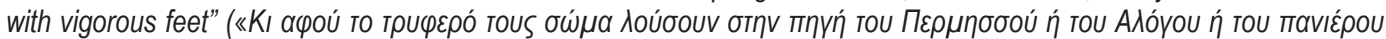

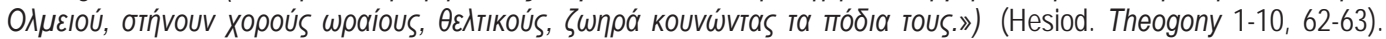
Also, in his description of Hercules' shield, Pseudohesiod presents music scenes, with Apollo playing music among the Muses who are dancing and singing in a circle (Homer. lliad $\Sigma$ 201-206, 270-285).

\section{The Nymphs}

The Nymphs were demons of nature residing in the springs and waters, as well as in mountains that had springs, in forests and prairies. They were believed to be Zeus' daughters and spirits of vegetation that danced and nurtured

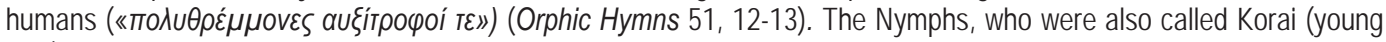
girls), were exactly the female version of Kouroi: ("Kouroi escorted Kouros-Zeus and Korai-Nymphs escorted Kore-

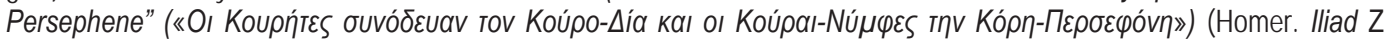
419, Homer. Odyssey Z 122; Pindar. Pythionikoi 3, 78; Euripides. Hercules 785). According to Hesiod, Kouroi and Kourai lived free in the nature where they danced, while Homer praised them for their beautiful dances and presented them dancing around the river Acheloos in Hepirus (Hesiod. Extract 198; Homer. Odyssey M 318; Homer. Iliad $\Omega$ 615). Their song and dance were accompanied by Hermes and Panas, who played the panpipe (Kakridis, 1986). Three Nymphs are depicted with gods Hermes and Panas in a votive relief in a cave. On the right, dedicator Agathemeros gives the 
kantharos (ancient Greek cup) to a wine steward to have his cup filled with wine (Fig.2).

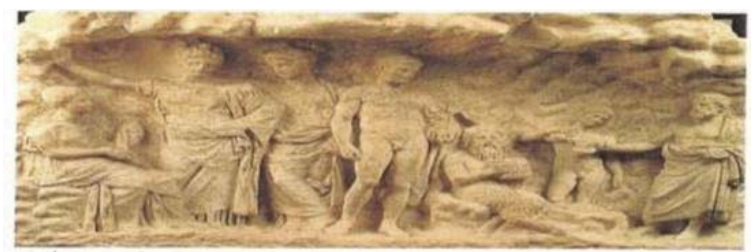

Figure 2. The Nymphs. Votive relief, around 310 B.C., Athens, National Archaeological Museum, 4466.

As demons of vegetation and particularly as "kourotrophoi" («коиротро́фо।»), i.e. immortal nurses taking care of divine

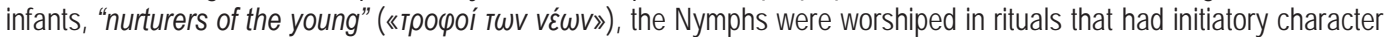
and confirmed the formal admission of the adolescents to adulthood (Hesiod. Theogony 346-348). This occurred with the performance of the "pyrrhic dance", a war dance with weapons during which the adolescent was judged for his ability in handling weapons (Lykesas \& Mouratidis, 2005). So, during the "pyrrhic dance" that unfolded the ritual of the passage to adulthood, the adolescent had the duty to display not only his physical abilities but also his worship intention (Connor, 1988). Besides "Kourai-Korai", the name of the Nymphs also meant young girls ready to get married and "vú $\varphi \varepsilon \varsigma$ " (brides) or newlywed girls. This mythic image of the Nymphs reflected a social reality concerning rituals in honor of goddess Artemis with the girls participating exalting the goddess through their dances. The most important of these ceremonies

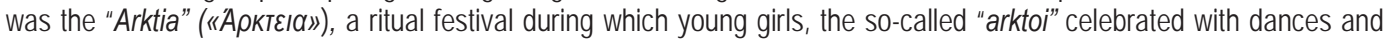
collective activities to worship Artemis Vrauronia in Attica. Here, the dance was the central topic and that is why it cannot be isolated as a separate individual element (Sourvinou-Inwood, 1968). Thus, the Arktia were interpreted as the ceremony representing the end of childhood and the transition to a time period when girls showed signs that they are ready for marriage (Burkert, 1993). At the same time, this kind of dances gave the opportunity to these young girls to get out of "Idia" ("IJIa"), that is the private space of their house, and find themselves outside in public, where they could be seen and flirted by their peer boys. It is exactly this that was illustrated in the relevant myth about the abduction of the Nymphs from the dance in honor of Artemis (Kakridis, 1986).

\section{The Maenads}

The Maenads represented the female followers of Dionysus. In the same way as Dionysus, they themselves also held the «Өúpбo» (thyrsus) in their hand, that is a stick covered with ivy or vine leaves, and sometimes with snakes or other

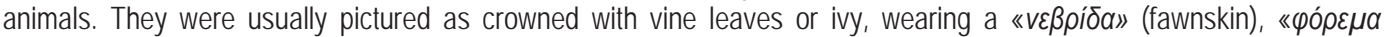

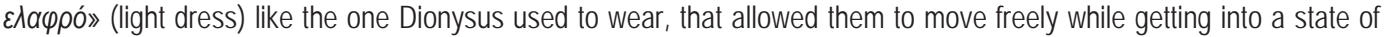
ecstatic frenzy (Fig.3).

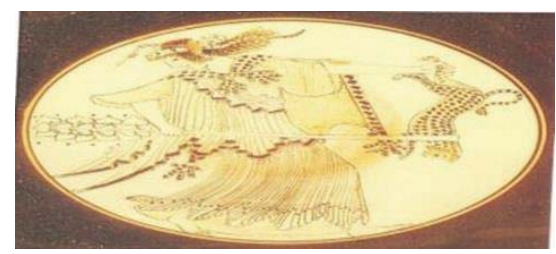

Figure 3. Interior of a cylix (wine-drinking cup) diameter $28 \mathrm{~cm}$, white depth, by Brygus' Painter. 490-485 B.C.Munich, Staatliche Antikesammlungen, 2645. Beazley, ARV2, 371.15.

We get information about the Maenads being Dionysus' female mates raging in a state of ecstatic frenzy in the mountains, from the Ancient Greek tragedians (Sophocles, Aeschylus, Euripides) and from many ancient sources, since Dionysus and the Maenads were among the most important features in the ancient Greek religion (Euripides. Bacchae 56, 62-63, 664, 726, 130-141; Sophocles. Extract 678). The Maenads would participate constantly in all festivals in the honor of Dionysus all over Greece, while their epithets differed from place to place. In Attica they were known as «Bákxa।» (Bacchae) from the homonymous work by Euripides: "....there they are described as "Dionysus" followers 


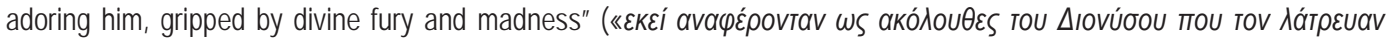

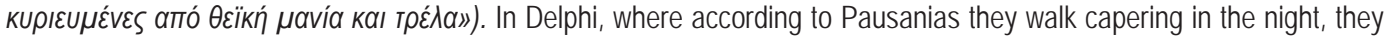
are mentioned as «Өuádalı (Thyiades), deriving from the verb "Oú $\omega$ " meaning "get mad, rage". In Peloponnese, they are

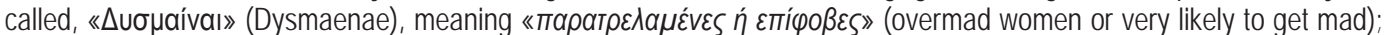

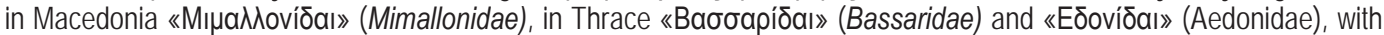
violent movements as the basic characteristic in their dance (Euripides. Bacchae 1001; Pausanias. 1. 19. 4; Liddell, \& Scott, 1972; Jeanmaire, 1985). The most "enthusiastic" musical instruments are the flute, drums, cymbals and rattles (Lekatsa, 1971). Taking into account all relevant references and findings, Emmanuel (1986) comes to the conclusion that the Maenads played the flute and drums, wore long robes waving with their movements, while their dance was synonymous to an overwhelming ecstatic rage that "carried them away" (Emmanuel, 1986). It is important to mention at this point the bacchic dance that is presented in the Palatine Anthology: there, a group of dancers, following a bacchic

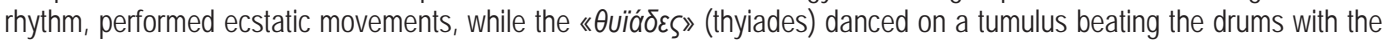
accompaniment of the flute (Anthology Palatine. 11.64, 7.485; Papaioannou, et al., 2009/2010). The basic step in the Maenads' dance was initially the zestful walking, which later on would turn into a run, as the vivacity of the dance increased. The direction of the dancers was mainly forwards, backwards and they made quite many rotations on the spot. Some extra figures included capers and bending of the body trunk, while hands had more freedom in their movement, quite often holding various objects. In addition, it seems that the dancers started dancing with their hair well done and, as the dance escalated in rhythm and passion, the hair slipped and moved back and forth untied in the air, something that characterized the overexcitation of the dance. (Lawler, 1972; Papaioannou \& Lykesas, ). In these cases, the head would usually lean backwards as an indication of the state of ecstatic frenzy. Jeanmaire (1985) supports that a Bacchic dance is primarily characterized by the body and head postures, rather than by the steps themselves (Jeanmaire, 1985). A Bacchante had to lift the right foot while elevating the thyrsus with his right hand (Euripides. Bacchae 941-943). This "bouncing" dance would result in the dancer's body being overwhelmed by a "bouncing pulse", technical term of ecstasis, getting detached from himself and getting carried away by its irresistible vehemence (Detienne, 1993).

From the above, it becomes obvious that the Maenads were possessed by the god's spirit, got engaged in an endless frenzied rowdy dance, with crazy indomitable and irregular movements that seemed like the leaps of the doe that tries to escape the hunter's persecution. At that moment their personality was temporarily "abolished", while they themselves entered a state of ecstasis known as "the supreme exaltation of Dionysus". In this state, the Maenads would express intense emotions and experience various emotional conditions. They would manifest a bizarre hyperactivity possessed by hallucinations, disorders of memory, judgement and vision (Fragkoulis, 1996). Intoxication and ecstasis would go on, while their phrenitis and delirium were accompanied with cymbals, tambourines and Lydian flutes (Ovidius. Metamorphoses 399-415). Their dance sometimes would become savage and scary for ordinary people, while insanity would lead them to outrageous acts (www.livepedia.grlindex). This specific behavior of these women could be characterized as the expression of an insane mind in overexcitation. In terms of etymology, their name derives from the

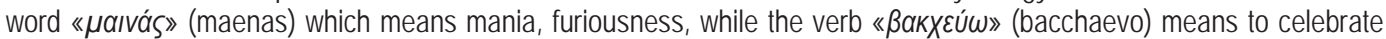
Bacchus' feast, to fall into a state of religious hysteria, dance, rage, get drunk (Liddell, \& Scott, 1972). It is also said that the Maenads' rage had no limits, for in the phase of Dionysian intoxication they tore apart animals and ate their flesh raw (Euripides. Bacchae 135-141, 862-867). Not even humans would escape their murderous insanity and delusion, as it is described in Orpheus' myth where the madding Bacchae savaged him (Euripides. Bacchae 119-120). In terms of the

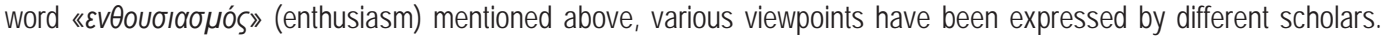

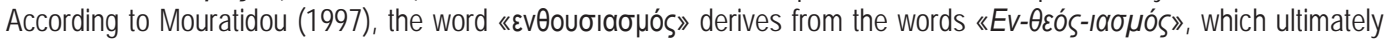
means "cure of god" (Mouratidou, 1997). Lekatsas (1971) supports that enthusiasm is one of the ways to get united with god and the primary means to achieve this are music and dance (Lekatsa, 1971). To Jeanmaire (1985), what the ancient Greeks called enthusiasm was the intense feeling of personality disruption and the occupation of the ego by a foreign person (Jeanmaire, 1985). Lastly, Plato characterizes enthusiasm as a condition that can result in extrasensory perception (clairvoyance) (Plato. Timaeus 71e). The Bacchic and manic condition incorporates divination, says Teiresias in Bacchae; actually a high degree of divination because "when overflowing bodies, god makes the struck from his mania

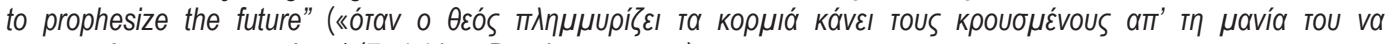

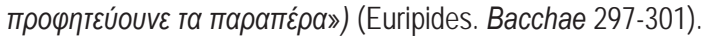

\section{Artemis}

Artemis is one of the oldest, most complex, but most interesting figures of the Greek pantheon. Daughter of Zeus and Leto, twin sister of Apollo, queen of mountains and forests, goddess of hunting and protector of small children and 
animals, she loved choral songs and dance (Simon, 1996) (Fig.4).

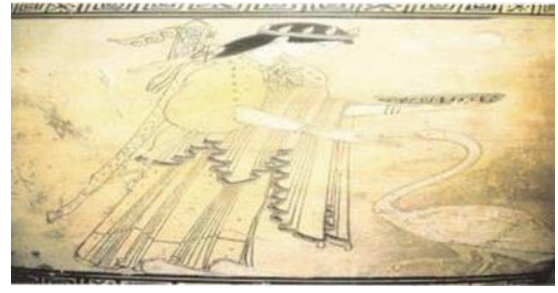

Figure 4. Artemis. White lekythos (oil flask) created by Pana's Painter. Around 490 B.C. Leningrand, Ermitage, Ermitage, 670. Beazley, ARV2, 557.121.

Her followers are depicted performing winding dances around her temple and altar, while in Homer's Hymn to Apollo, she herself is described dancing, following the melody of Apollo's Olympian music, together with the Nymphs of the mountains that follow her also at hunting (Euripides. Iphigenia in Aulis 1480-1484; Homer. Hymn to Apollo 194; Homer. Odyssey Z 102). This image of Artemis being followed by the Nymphs, hunting, dancing and playing in the mountains and prairies, will be maintained in all subsequent descriptions of hers. That is why in another Homeric hymn, Artemis is

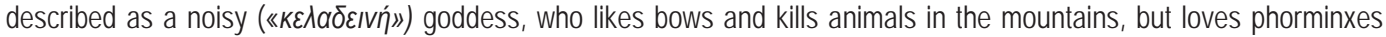
and dances, loud cries and shady groves (Homer. Hymn to Aphrodite 18-20). In Ephesus, which used to be one of the major worshipping centres of the goddess, there was a myth saying that her sanctuary had been founded long before by the Amazons, who placed a model of Artemis under a willow and performed two dances around her, one war dance with weapons and one circular dance, accompanied by the acute sounds of the syrinx (Callimachus. Hymn to Artemis 237247). It was from such a location dedicated to the goddess that Hermes kidnapped Polymele, the most beautiful of the girls participating in the dance of Golden-Bowed Artemis (Homer. Iliad $\Pi$ 180-185).

Yet, Artemis was worshipped in other areas of Greece as well, where she was called with many different local names. So, in Karyes the goddess was called "Artemis Karyatis" and was identified with Nymph Karya. It is known from sources that young virgins of Sparta, the Karyatides, who used to be the models of the Karyatides' sculptures, performed

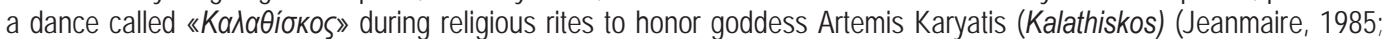
Lykesas \& Mouratidis, 2005). The main feature of this dance was the basket (kalathiskos) that the female dancers had on their heads while dancing, and that is where its name was taken from. Furthermore, Artemis Karyatis was worshipped by rural and pastoral populations of Lakonia with orgiastic dances and obscene songs, the so-called "astravika" («aбтраßıкর́»)) ("astravi" was the saddle of the animal on which the followers singing the "astravika" were transported (Apollodorus. Library 1, 4, 1). More specifically, it seems that Gaea, who had been worshiped before as Mother Goddess in ancient Olympia, over time either took the name of Artemis or was replaced by her, for quite many worshipping altars of the latter have been found around the area of Olympia (Pausanias. 5. 14. 5, 6. 22. 8). Besides, the connections of Artemis with Olympia are numerous and date back to the prehistoric times. The goddess was connected with the river

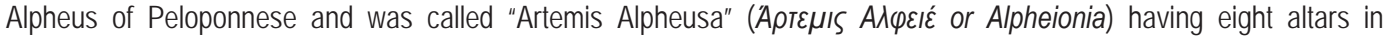
Olympia, where every year a feast was held to honor her and every month she received sacrifices from her followers (Pindar. Nemeonikos 1.1-6; Athenaeus. Deipnosophistai 346; Pausanias. 5. 14. 5, 6. 22. 8). In the region of Letrines

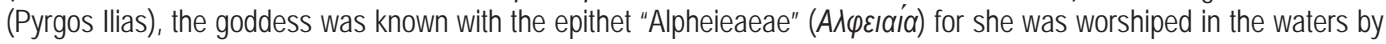
the mouth of the Alpheus river and in the surrounding fertile grounds. According to a local myth, the goddess had an overnight joyful gathering there with the nymphs in her retinue having their faces covered with clay (Pausanias. 6. 22.10).

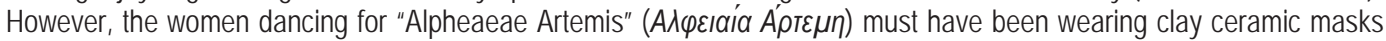
instead of plain clay (Papachatzis, 1987). In many places in Greece, Artemis replaced the Minoan goddess of birth Eileithyia, who survived in other places with the same name during the historical era. The Olympian goddess then

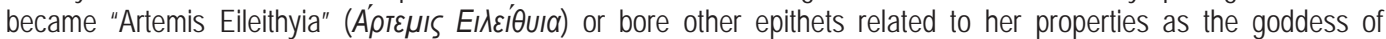
childbirth and midwifery (Papachatzis, 1987). The primary reason to worship a virgin goddess of childbirth was the fact that Artemis herself was a virgin nature. The girls that were just about to get married and were to lose their virginity, had

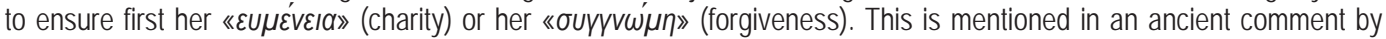
Theocritus (Theocritus. Idyll 2.66-67) when Anaxo, who she was in love with, was wandering in a forest of Artemis: "The virgins who have decided to get married ask from Artemis to forgive them, because they wish to avoid the goddess'

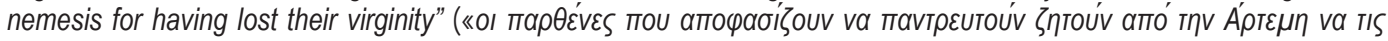




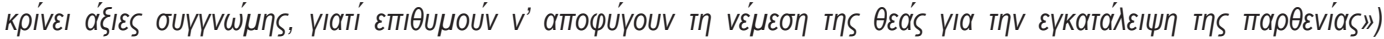
(Papachatzis, 1987). All over Greece, girls that are about to enter adulthood form dancing groups particularly in feasts in honor of the goddess. This is at the same time one of the greatest opportunities for the young boys to get to know the

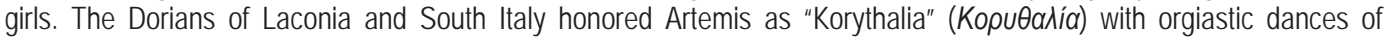
women, who had their faces covered with wooden masks (Hesychius, L. korythalistriai). In Lesvos, the goddess was

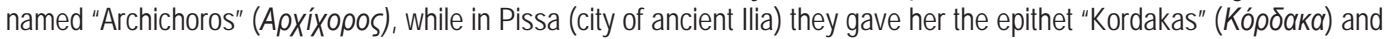
was honored by men who were dancing the homonymous dance with feminine movements (Pausanias. 6. 22. 1). Finally, in her honor were held the «Artemisian Mysteries», where races were held with a procession of the statue of the goddess dressed in a wild animal's fawnskin. The procession would close by a group of girls dancing disguised as nymphs (Apollodorus. Library 1, 4, 1). In conclusion, it seems that Artemis was connected with the dance, since times she is presented dancing under the sound of the Olympian music either alone or accompanied with the Nymphs.

\section{Aphrodite and the Graces (Charites)}

The position of Aphrodite as goddess of beauty and love determined her role in Semitic and early Greek doctrines and rites, related to fertility and natural procedures towards rejuvenation and reproduction. In these rituals, as Lucian mentions, the dance was associated with the most ancient god of all, Eros (Lucian. The dance 7-8). In mythology, Aphrodite was considered to be the mother of god Eros and, as such, she is closely connected with dance, for dance itself in its turn is also a mouthpiece of Eros. Eros is the one who leads all feasts, dances and sacrifices (Plato. Symposium 197d). Moreover, the relation of the goddess with the dance is captured twice in the ancient Greek literature. First, Poet Sappho in one of her poems invites Aphrodite's spirit to come down to the garden and grove, where a group of women dance and sing in her honor (Sappho, extract 2). Also, in the Hymn to Apollo, Aphrodite is presented dancing on Mount Olympus with Ores and Graces while Apollo plays his lyre (Homer. Hymn to Apollo 194). The Graces were primeval pre-Hellenic "aphrodisian" deities, and mythological women, who offered fertility to the soil and grace to the humans. Over time, these features passed on to Aphrodite completing her image and the Graces themselves became the goddess' attendants (Herodotus. Euterpe 51.2 ).

Polydefkis wrote about the dance of Graces aiming at euphoria and mirth, while Homer in Odyssey exalted the passionate sensual dance of the Graces, in which Aphrodite herself also took part (Polydefkis 4, 95; Homer. Odyssey $\Sigma$ 194). In addition, two representations complete the image of the Graces with regard to dance: the goddesses are depicted dancing with little Eros in an Archaic votive relief from the Acropolis of Athens. Each one of the Graces holds with her left hand the wrist of the right hand of the next one, and in the end follows little Eros held with the same grip. This

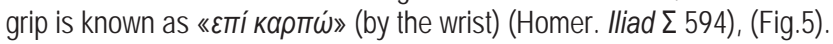

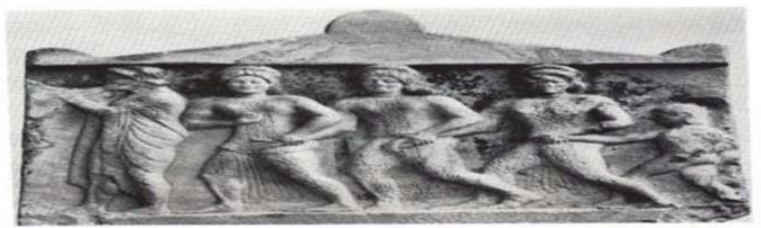

Figure 5. Votive relief of the Graces (Charites) from the Acropolis in Athens. About 510/500 B.C. Athens, Acropolis Museum, 702.

\section{Demeter and Persephone}

Demeter was the goddess of agriculture and harvest, mother of Persephone. She was worshiped in Eleusina, where the Eleusinian Mysteries were held in honor of her and her daughter (Hesychius. L. Eleusinia; Athenaeus. Deipnosophistai 13, 609e; Pausanias. 2. 14. 1). Demeter and Persephone belonged to the deities of vegetation and were considered to be goddesses of fruit, but also of the dead. Thus, there were respective dances and songs about birth and death (Kakridis, 1986). There were many feasts to honor Demeter and Persephone. Some of these were celebrated in the spring -when it was believed that Persephone ascended from the underworld. Others were celebrated in autumn and concerned the journey of the seed in the soil until it grows and comes out in the light the following spring -in exactly the same way as Persephone who separates from Demeter to go down to the underworld and meets her again every spring (Lawler, 
1984). The characteristic feature in these feasts was the performance of dances by female dancers, who represented with their movements the various phases of the mother seeking her daughter. Furthermore, the women who participated in the "Thesmophoria", the most popular feast in honor of goddess Demeter, danced vivacious brisk dances in the countryside, as a form of invocation addressed to the goddess to ask for fertility of the soil and human species (Simon, 1996; Hesychius. Lexicon, Thesmophoria). Such a ritual is described by Aristophanes in his work "Thesmophoriazusae": He calls his dances "orgies" (ópyıa), a word that implies secrecy and mysticism. Their rhythm was alternating, as they are described to be lively and brisk forming a circle in the beginning, and then they became quiet and measured. The slow pace of dances was associated with the dancers' making invocations to various deities; once this invocation was over, the dances would gain again the fast pace with the dancers dancing in a double row (Aristophanes. Thesmophoriazusae 947-1000).

\section{Cybele}

Cybele was the Phrygian deity of nature, vegetation, fruition, maternity and generally of fertility. Her followers worshiped her in the mountains, in the wild nature, with orgiastic rites, loud screams, and the sounds of drums, flutes and cymbals (Pausanias. 7. 17. 9). She was considered the mother and breast feeder of gods and humans, since it was her who held humans in her arms when they came to this life and departed from this life. In addition, she ruled over mountains and wild beasts, protected cities and social institutions and was the mistress of augury and medicine (Kopsachilis, 1992). The rural character of Cybele's cult with the intense emotional element and the imposing religious rites rendered the goddess popular to grassroots and particularly to women. In a votive relief of the $3^{\text {rd }}$ century B.C., the goddess is depicted holding the wand in one hand and the drum in the other one. Right next to her stand her sacred animal, the lion, and her beloved Attis (Fig.6).

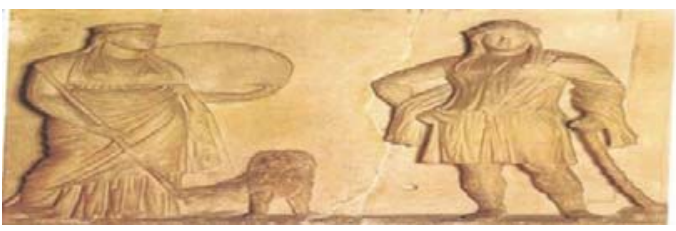

Figure 6. Cybele and Attis. Votive relief. Around 230 B.C. Venice, Archaeological Museum, 118.

In the historical course of religious cults in the Greek world, Cybele had many common elements with Gaia, Demeter, Aphrodite, Athena and Artemis. In the end, she was identified with Rheia, who was the only undisputable mother of gods -at least according to the official Olympian religion of the Greeks (Kopsachilis, 1992). Thus, the content and meaning of Cybele's cult seemed from the very beginning familiar to the Greeks, who had no difficulty in accepting and integrating it

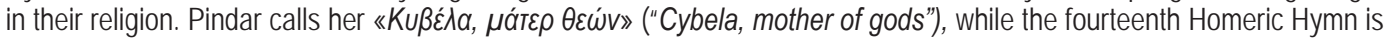
dedicated «Eís Mrićpa $\theta \varepsilon \dot{c} v$ », i.e. to the Mother of all gods and humans, who "is well-pleased with the sound of timbrels and rattles, with the voice of flutes and the outcry of wolves and bright-eyed lions, with echoing hills and wooded

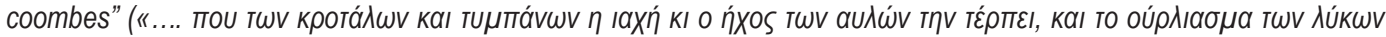

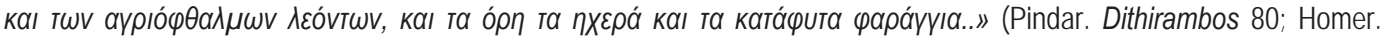
Hymn to the Mother Gods 14). Cybele is often depicted holding a drum, something which probably means that in her rites, these musical instruments were often used. It appears that the drums were common in Cybele's and Dionysus' rites. The persistent drum-beating was characteristic of the orgiastic dances and helped the followers to reach a state of ecstasis (Lawler, 1984).

As a goddess of nature, Cybele was usually worshiped in outdoor sanctuaries. It is mentioned that her followers worshiped her on the mountains with wild cries, noisy music of kettledrums, rattles, flutes and cymbels, with frenzied dances, hair tearing, self-injuries and self-castrations (Kakridis, 1986; Kopsachilis, 1992). Her cult was characterized by orgiastic frenzied dances and very loud and highly stimulating music. All the above appear the same as in the respective cult in honor of Dionysus (Burkert, 1993). Probably this is the reason why Cybele's cult has been connected very early in Greece with the cult of Dionysus, who was also very popular in the grassroots. However, the Greeks who adopted this worship, limited its wildness which did not match their character. 


\section{Conclusions}

The dance was so important in ancient Greece that we have innumerable scripts and pictures related to it. The dance did not have only entertaining character as an outlet for intense emotional outbreaks, but it was also the original worship medium that was never absent from any religious rite (Lucian. The dance 15). To the ancient Greeks, the dance constituted an indispensable part of all events in their life. All their daily occupations, as well as their supernatural concerns, were connected with dance and music, which were the most popular arts of their time. The «apuovía» (harmony) they seeked through music and "үú $\mu v a \sigma \eta »$ (gymnasis =exercising) of both the body and the soul through dancing, featured indeed the entire philosophy of that era. Dance, music and poetry were the three elements that managed to affect and form the education of the ancient Greeks and lead to the configuration of the most fundamental

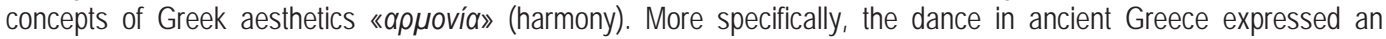
emotional state that brought together social harmony with cosmic harmony (Miller, 1986); it united the ecstatic and wild element with the peaceful element of the soul; it had a characteristic function in the worship procedure; besides the therapeutic purifying effect it had on the participants, it also aimed at the relaxation and redemption of the soul, the spiritual liberation from tensions and restrictions of social life. The ancient Greeks regarded dance as a kind of spiritual divine substance, gift of the immortal gods to the humans and a means to communicate with them. The Greeks' supernatural anxiety was cured through religion which was manifested with hymns and worshiping dances. (Vernant, 1995). It was through dancing that the humans honored, invoked with praise, thanked the gods and, at the same time, were amused and benefited (Lucian. The dance 23). It was actually an outbreak of mental impulses, a mental response to a variety of emotions. Thus, dance functioned as a means to express mental states and as an indication of religious faith and commitment with the use of rhythmic movements.

In ancient Greece, it was widely believed that the dance was the opportunity for the gods' will to intervene to human issues. This meeting of divine archetypes and human manifestations through dance can be understood only if we realize the aim of the feast as a foundation for the religious experience. Female deities were leading the dances having numerous names - Muses, Nymphs, Maenads and deities of the Greek "Dodekatheo" (the twelve Olympians); they appear as "Khoregoi" (Xopayoí), i.e. chorus leaders who are invoked by their followers during the feasts and the overnight rites and orgies (Sophocles. Antigone 1146-1148). They have been identified also with other deities in the Greek territory and Asia, have absorbed local female deities, have been established in the Greek pantheon and have exerted great influence on the religious consciousness of the Greeks. In worship, the dance had also a purely initiating character.

All in all, to the ancient Greeks dance was an integrated way to experience the world for at the same time it incorporated knowledge, art and religion. They danced and served deities either to invoke them or to celebrate and honor them. The dance was the complete wisdom that constituted the creative power of every human being, constantly regenerating and acting on the human soul. Thus, the tradition activates the myth, the process of being reborn, living again all over from the beginning, igniting the binary nature inside every soul (i.e. the human and the divine element), and thrusting the future and personal evolution. Surely there are all those difficulties that prevent the researcher from drawing safe conclusions about the ritual practice of all these worshiping procedures. The difficulties emerge due to the insufficiency of resources, their contradictions, their fragmentation, the mysticity during the rites and lastly the long chronic distance from the contemporary era. Therefore, it is natural to have questions that still remain unanswered. However, we hope that going through the resources in this present study has led to plausible conclusions that reflect the historical reality to the best possible extent. In any case, no matter what the real nature of these female deities and their cults was, they will never stop stimulating our interest and admiration.

\section{References}

Adshead, J. \& Layson, J. (1986). Dance History. A Methodology for Study, Dance Books Ltd, London.

Athenaeus. Deipnosophistai 13, 346, 609e.

Alexiadou, K. (1999). Music and Movement Education Carl Orff. Modem nursery school, Vol 9, pp. 171-175

Anthology Palatine. 11.64, 7.485.

Apollodorus. Library 1, 4, 1.

Aristotle. Politics 1337a-1340b.

Aristophanes. Thesmophoriazusae 947-1000.

Burkert, W. (1993). Ancient Greek Religion. Trans. Batzantakos,N.P. \& A. Abagianou, A. Athens.

Callimachus. Hymn to Artemis 237-247.

Connor, R.W. (1988). Early Greek Land Warfare as Symbolic Expression, P\&P, Edinburgh. 
Detienne, M. (1993). Dionysus under the stars. Athens.

Emmanuel, M. (1986). La danse Grecque antique, Paris.

Euripides. Bacchae 56, 62-63, 664, 726, 119-120, 130-141, 297-301, 862-867, 941-943, 1001. Iphigenia in Aulis 1037-1043, 1480-1484. Hercules 785.

Fragkoulis, A. (1996). Euripides Bacchae, Introduction and Notes. Athens.

Jeanmaire, H. (1985). Dionysus, History of the cult of Bacchus. Trans. Mertani, A.L., Athens.

Hesiod. Extract 198, Projects and days 1, Theogony 1-115, 346-348, Shield 200-206.

Herodotus. Euterpe 51.2.

Hesychius. Lexicon. Eleusinia, Thesmophoria, Korythalistriai.

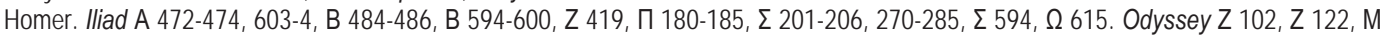
318, $\Sigma$ 194. Hymn to Apollo 185-189, Hymn to the Mother Gods 14. Hymn to Aphrodite 18-20.194 к.ع.

Kakridis, Th. I. (1986). Greek Mythology. Vol. B, Athens.

Komninou-Printaki, A. (1998). The Social and Educational Philosophy of the Orff Pedagogic Project. Music education - Proceedings of the 1st National Conference of E.E.M.E. Thessaloniki, Vol 3, pp. 14-22.

Kopsachilis, I. (1992). Music in Ancient Macedonia. Thessaloniki.

Kraus, R (1980). History of Dance. Trans. Sidiropoulos, G. \& Kakavoulia, M., Athens.

Lawler, B. L. (1972). The Maenads. A contribution to the study of the Dance in Ancient Greece: Memories of the American Academy in Rome Vol.6, pp. 69.

Lawler B. (1984). Dance in Ancient Greece. Trans. Dimitriadi-Pharopoulou, M., Athens.

Lekatsa, P. (1971). Dionysus, origins and evolution of the Dionysian religion. Athens.

Liddell, G. H. \& Scott, R. (1972). Great Lexicon of the Greek Language. Trans. Moschou P.X., Sideris Athens.Lucian. The dance 7-8, 15, 23.

Lucian. The dance 7-8. Peri orchiseos 15.

Lykesas, G. \& Mouratidis, I. (2005). Dance during the classical period in Greece, Athens and Sparta. Revista teoretico-metodica, Stiinta Sportului. Institutul National de Cercetare pentru Sport, 46, 3-21.

Miller, J. (1986). The Measures of Wisdom. The Cosmic Dance in Classical and Christian Antiquity. University of Toronto, Toronto.

Mouratidis, I. (1998). History of Physical Education, Thessaloniki.

Mouratidou, K. (1997). Chorotherapeutic elements in ancient and modern Greece. Sports and Society. 1997; Vol. 18, pp. 65 -72.

Mouratidou, K., Anastasiou, A. \& Mouratidou, A. (2002). The character of the dance in ancient Greece through the visual arts. Sports Performance and Health. Vol. 4, pp. 253-263.

Neubecker, J. A. (1986). Music in Ancient Greece. Trans. Sirnota-Fidegi. Odysseas. Athens.

Orphic Hymns 51, 12-13.

Ovidius. Metamorphoses 399-415.

Panagou- Michalakakos, B. (2003) «Ancient Orchisi» in: Pref. Gyftoula, N. et. al. Arts II: Review Greek music and dance, Theory Dance - Greek Dance Act: Ancient and Middle Age, Vol. D. E.A.P. Patra.

Papadopoulou, Z. (2004). Dances of Apollo. Sparta -Delos -Delphi. Archeology and arts, 90, 29-33.

Papaioannou, Ch., Mouratidou, K., Mouratidis, I. \& Douka, S. (2009/2010). The role of women in the dance of the cult of Dionysus in ancient Greece. Woman \& Sports.: VII, pp. 122 -125.

Papaioannou, Ch., Lykesas, G. (2012). The role and significance of dance in the Dionysian Mysteries. Studies in Physical Culture and Tourism. Vol. 19, No. 2, 2012, 68-72.

Papachatzis, N. (1987). History of the Greek Nation. Athens.

Pausanias. 1. 19. 4, 2.14. 1, 5. 14. 5, 6. 22. 1, 6. 22. 8, 7. 17. 9, 6. 22.10.

Pindar. Dithirambos, extract 80, Pythionikoi 3, 78, Nemeonikos 1.1-6.

Plato. Laws 653c-d, 665a, 654B, 814-817, Symposium 197d, Timaeus 71e.

Polydefkis. 4, 95.

Sappho. extract 2.

Simon, E. (1996). The Gods of the Ancient Greeks. Trans. Pingiatoglou, S., Thessaloniki.

Sophocles. Antigone 1146-1148, Extract 678.

Sourvinou-Inwood, C. (1968). Studies in Girls Transitions, Athens.

Themelis, D. (1989).Zwei neue Funde altgriechischen Musik aus Laureotike und Pelion. Die Musikforschung 42, Heft 4, s.307- 325.

Themelis, D. (1994). Eine antike Musikinschrift aus dem Heiligtum des Herakles Pankrates. Die Musikforschung 47, Heft 4, 349- 364.

Theocritus. Idyll 2.66-67

Vernant, P. J. (1995). The Greeks, Chicago.

West, L. M. (1999). Ancient Greek Music. Trans. Komninos, S.,Athens.

www.livepedia.grlindex. 